\title{
A comparison of eddy-covariance and large aperture scintillometer measurements with respect to the energy balance closure problem
}

\author{
S. M. Liu ${ }^{1}$, Z. W. Xu ${ }^{1}$, W. Z. Wang ${ }^{2}$, Z. Z. Jia ${ }^{1}$, M. J. Zhu ${ }^{1}$, J. Bai ${ }^{1}$, and J. M. Wang ${ }^{2}$ \\ ${ }^{1}$ State key laboratory of Remote Sensing Science, School of Geography, Beijing Normal University, Beijing, 100875, China \\ ${ }^{2}$ Cold and Arid Regions Environmental and Engineering Research Institute, Chinese Academy of Sciences, \\ Lanzhou, 730000, China
}

Received: 20 October 2010 - Published in Hydrol. Earth Syst. Sci. Discuss.: 4 November 2010

Revised: 13 April 2011 - Accepted: 14 April 2011 - Published: 26 April 2011

\begin{abstract}
We analyzed the seasonal variations of energy balance components over three different surfaces: irrigated cropland (Yingke, YK), alpine meadow (A'rou, AR), and spruce forest (Guantan, GT). The energy balance components were measured using eddy covariance (EC) systems and a large aperture scintillometer (LAS) in the Heihe River Basin, China, in 2008 and 2009. We also determined the source areas of the EC and LAS measurements with a footprint model for each site and discussed the differences between the sensible heat fluxes measured with EC and LAS at AR. The results show that the main EC source areas were within a radius of $250 \mathrm{~m}$ at all of the sites. The main source area for the LAS (with a path length of $2390 \mathrm{~m}$ ) stretched along a path line approximately $2000 \mathrm{~m}$ long and $700 \mathrm{~m}$ wide. The surface characteristics in the source areas changed with the season at each site, and there were characteristic seasonal variations in the energy balance components at all of the sites. The sensible heat flux was the main term of the energy budget during the dormant season. During the growing season, however, the latent heat flux dominated the energy budget, and an obvious "oasis effect" was observed at YK. The sensible heat fluxes measured by LAS at AR were larger than those measured by EC at the same site. This difference seems to be caused by the so-called energy imbalance phenomenon, the heterogeneity of the underlying surfaces, and the difference between the source areas of the LAS and EC measurements.
\end{abstract}

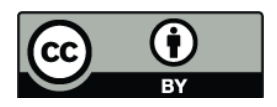

Correspondence to: S. M. Liu (smliu@bnu.edu.cn)

\section{Introduction}

Energy and water vapor interactions between land surfaces and the atmosphere are the most crucial ecological processes in terrestrial ecosystems (Baldocchi et al., 1997). These interactions determine the long-range transport of heat, humidity, and pollutants, and the growth rate and properties of the planetary boundary layer (Wilson and Baldocchi, 2000). Therefore, the quantitative estimation of the energy and water vapor flux (the sensible heat and latent heat fluxes) is crucially important for the appropriate use of water resources and environmental protection, particularly in arid and semiarid regions.

The eddy covariance (EC) method has been widely applied to measure the exchange of energy, water vapor, and carbon dioxide between the land surface and the atmosphere. Currently, this technique is considered a standard method for measuring surface fluxes (Aubinet et al., 2000). Many reports have been published about the use of the EC system to measure the energy and water vapor fluxes in a variety of ecosystems, including forests (Wilson and Baldocchi, 2000), grasslands (Wever et al., 2002) and farmlands (Suyker and Verma, 2008). Nevertheless, the EC method has limitations. Reliable measurements are restricted by many factors, such as complex conditions (e.g., topography and unfavorable weather), and corrections need to be applied when processing the turbulence data (Finnigan et al., 2003). Hammerle et al. (2007) and Hiller et al. (2008) have successfully used the EC method under such complex conditions with rigorous data processing. However, Mauder et al. (2007a) have documented that different data processing schemes can lead to errors as large as $10 \%-15 \%$. Additionally, one of the most important problems is the "energy imbalance" in applying

Published by Copernicus Publications on behalf of the European Geosciences Union. 
the EC data to the energy budget. Wilson et al. (2002) have discussed this issue and summarized the causes of the imbalance as follows: (i) a mismatch in source areas for the energy budget terms, (ii) a systematic bias in instrumentation, (iii) a failure to consider energy sinks, (iv) a loss of low- and/or high-frequency contributions to turbulent fluxes, and (v) a failure to consider the advection effect. Several scientists (e.g., Cava et al., 2008; Foken, 2008) have recently grouped these causes into three main categories: (i) errors associated with measurement processes, (ii) errors associated with different scales or layers, and (iii) errors produced by a loss of low- and/or high-frequency contributions to the energy transport. Von Randow et al. (2008) emphasized that the contribution of low-frequency eddies to the energy transport, which were not "captured by the EC", may be the main reason for the energy imbalance. Many scientists have also used the large-eddy simulation (LES) model to study the imbalance problem. This method gives us a better understanding of the physical processes that lead to fluxes on scales at which conventional single EC tower measurements are unable to detect, and such imbalances have been attributed to turbulent organized structures (TOS) (Kanda et al., 2004; Steinfeld et al., 2007). In recent studies, it was found that the non-closure of the energy balance was explained by the energy fluxes from secondary circulations and larger eddies that cannot be captured by EC measurement at a single station. The spatially averaging methods (such as scintillometers, airborne EC and the spatial EC method) may exhibit a tendency to close the energy balance (Mauder et al., 2008; Foken et al., 2010).

In addition to the EC system above, for the last few decades, the large aperture scintillometer (LAS) has been widely used to measure turbulent fluxes, and reliable results have been obtained for both homogeneous and heterogeneous underlying surfaces (Hoedjes et al., 2002; Meijninger et al., 2002a). A LAS can obtain the area-averaged sensible heat flux, and the area-averaged evapotranspiration (ET) can be derived from the energy balance equation if the surface available energy (the net radiation minus the soil heat flux) is known (Meijninger et al., 2002b). Because the path lengths of the scintillometer are comparable to the pixel size of satellite images and area-averaged surface fluxes are obtained, the scintillometer has broad applications (McAneney et al., 1995; Foken et al., 2010). However, the LAS also has its limitations, such as meteorological limitations in longterm operations, which include precipitation, poor visibility, and weak turbulence, and methodological limitations such as signal saturation, inner-scale dependence of the signal, and tower vibrations (Moene et al., 2009). Thus, data processing must be carried out carefully, especially under complex conditions (Meijninger et al., 2002a).

The Heihe River Basin is located in the arid and semiarid regions of Northwest China, with the unique landscape of "ice/frozen soil-forest-river and wetland-oasis-desert", which are connected by a water system. As an important component of the project "Watershed Allied Telemetry
Experimental Research (WATER)", many observation sites were established in late 2007 to measure the surface fluxes of momentum, energy, and water vapor on various land surfaces to better understanding of the characteristics of surfaceatmosphere exchange and to develop, improve, and validate land surface and hydrological models (Li et al., 2009, 2011).

The main objectives of this paper were as follows: (i) to analyze the spatial representatives of flux measurements by EC and LAS systems over different surfaces, (ii) to study the seasonal variation characteristics of energy balance components over different surfaces, and (iii) to compare the sensible heat fluxes obtained with LAS and EC.

\section{Materials and methods}

\subsection{Site description and instrument}

Our study was conducted in the Heihe River Basin, and three sites were selected: Yingke (YK, $100^{\circ} 24^{\prime} 37^{\prime \prime} \mathrm{E}, 38^{\circ} 51^{\prime}$ $26^{\prime \prime} \mathrm{N} ; 1519 \mathrm{~m}$ ), A'rou (AR, $100^{\circ} 27^{\prime} 53^{\prime \prime} \mathrm{E}, 38^{\circ} 02^{\prime} 40^{\prime \prime} \mathrm{N}$; $3033 \mathrm{~m}$ ), and Guantan (GT, $100^{\circ} 15^{\prime} 1^{\prime \prime} \mathrm{E}, 38^{\circ} 32^{\prime} 1^{\prime \prime} \mathrm{N} ; 2835$ $\mathrm{m})$. The three sites represent the different kinds of climate and land covers that characterize the Heihe River Basin (Fig. 1). The YK site is located in the middle reaches of the Heihe River Basin, with an average annual temperature and annual precipitation of $7.2^{\circ} \mathrm{C}$ and $126.7 \mathrm{~mm}$ (1960-2000), respectively. The AR site is located in the upper reaches of the Heihe River Basin, with an average annual temperature and annual precipitation of $0.9^{\circ} \mathrm{C}$ and $403.1 \mathrm{~mm}$ (19602000), respectively. The GT site is located in the middle reaches of the Heihe River Basin, with an average annual temperature and annual precipitation of $3.2^{\circ} \mathrm{C}$ and $333.7 \mathrm{~mm}$ (1960-2000), respectively. The soil texture is silt loam at YK, sand mixed with silt at AR, and sand covered with moss at GT. The YK site is located in an irrigated field in which maize was interplanted with spring wheat from May to July and maize only from August to September (the maximum height of the spring wheat and maize are approximately $1 \mathrm{~m}$ and $1.8 \mathrm{~m}$, respectively). YK is in a typical oasis with very flat terrain, approximately $8 \mathrm{~km}$ southwest of Zhangye City, and it is surrounded by the Gobi (approximately $7 \mathrm{~km}$ from the site, Fig. 2a). AR is located in a valley oriented in an eastwest direction, with a maximum width of $3 \mathrm{~km}$ from north to south. The terrain around AR is relatively flat, with a gentle decline from the southeast to the northwest. The areas near the LAS transmitter and receiver both have sloping topography. The EC system was installed in the center of the terrain around AR (approximately $1300 \mathrm{~m}$ along a nearly flat terrain from south to north), which was $900 \mathrm{~m}$ away from the LAS receiver (Fig. 2b). The land surface was covered with alpine meadow at AR (the maximum height of the grass was approximately $0.2-0.3 \mathrm{~m}$ during the growing season). GT is located in the Dayekou watersheds, and continuous mountains surround the site. The EC system was installed on a relatively 


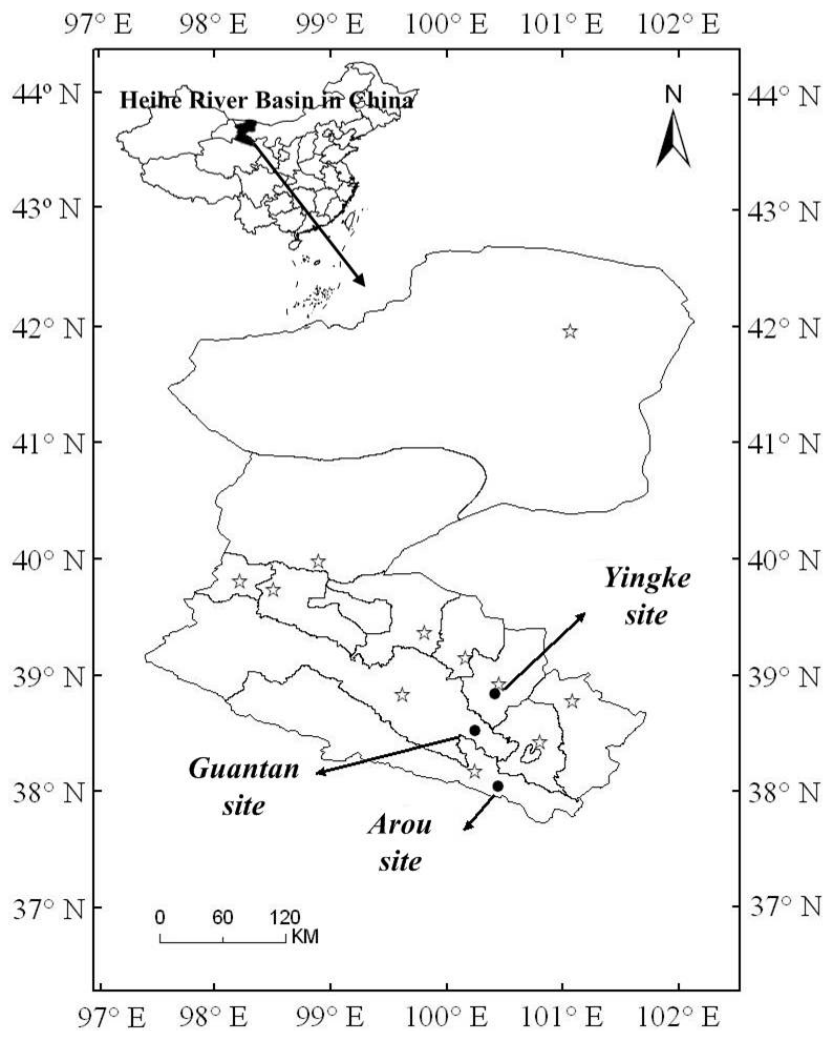

Fig. 1. Locations of observation sites (the star symbol represents the city in the Heihe River Basin).

flat terrain, located in the mountainside, with rolling topography. The forest surrounding the EC tower was Qinghai spruce $18-20 \mathrm{~m}$ in height, and the ground was covered with moss $0.1 \mathrm{~m}$ high (Fig. 2c).

Each of the three sites had EC and automatic weather station (AWS) systems, and a set of LAS was installed at AR. Detailed information regarding each observation site is listed in Table 1. The EC sensors were installed at heights of $2.81 \mathrm{~m}, 3.15 \mathrm{~m}$, and $20.25 \mathrm{~m}$ above the ground at $\mathrm{YK}, \mathrm{AR}$, and GT, respectively. The EC data were sampled at a frequency of $10 \mathrm{~Hz}$ at all of the sites, and the turbulent fluxes were recorded by a data logger (CR5000, Campbell Scientific Inc.). At AR, the LAS transmitter and receiver were installed on a pair of towers $2390 \mathrm{~m}$ apart. A Global Positioning System (GPS) was used to obtain the LAS locations, and the transect profile, including the longitude, latitude and elevation, was taken at 50-m intervals along an optical path. Combined with the LAS weighting function, the effective height at site AR was calculated at $9.5 \mathrm{~m}$ using the method of Hartogensis et al. (2003) (Eq. 15 in the reference). The LAS data were recorded on the signal processing unit (SPU) designed by Scintec at a sampling frequency of $5 \mathrm{~Hz}$. The EC and LAS data were processed with an average time of $30 \mathrm{~min}$. AWS was installed at each site to obtain the data of air temperature and humidity, wind speed and direction, air

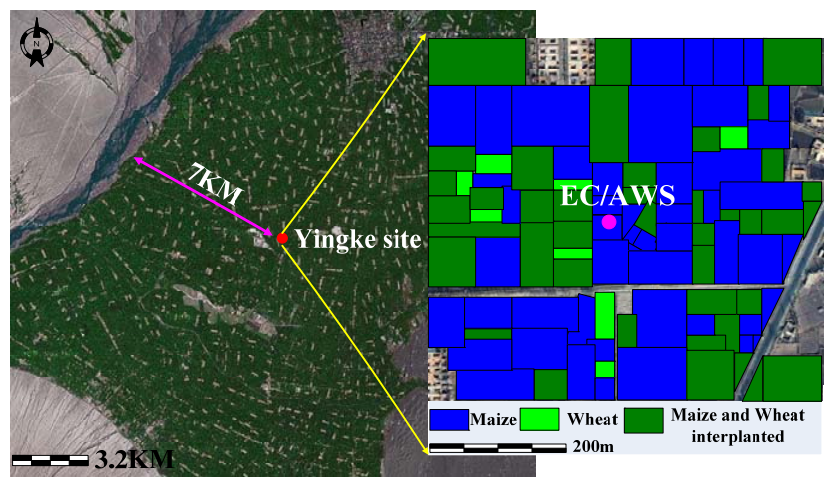

(a)

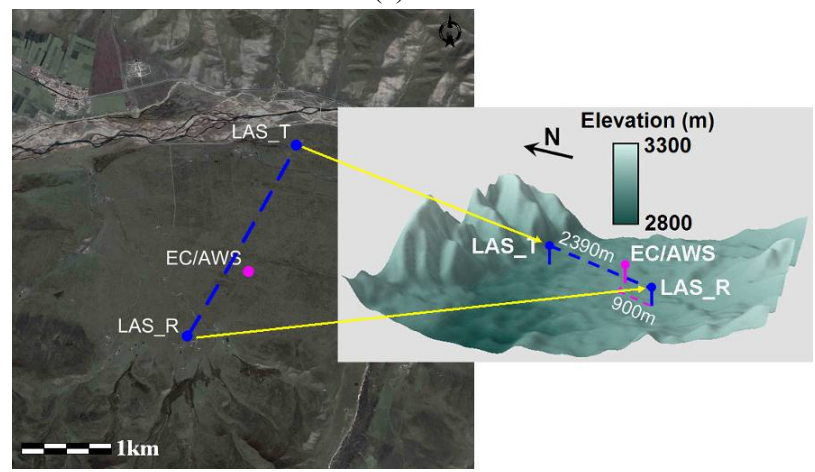

(b)

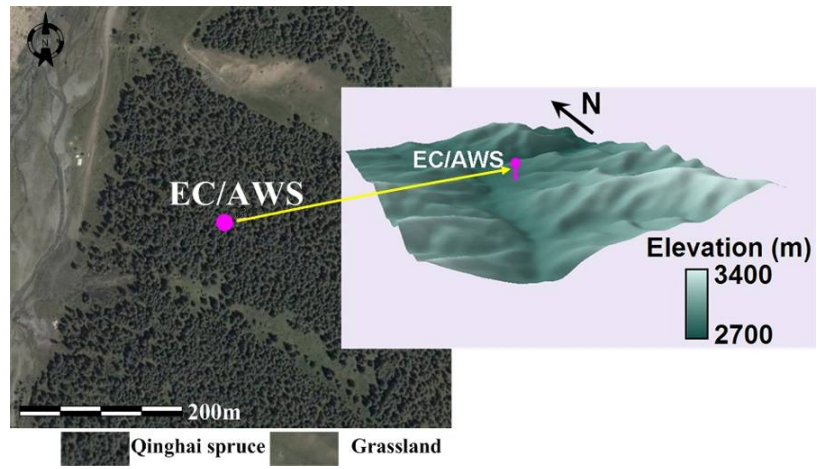

(c)

Fig. 2. Overview of the observation sites: (a) YK; (b) AR; and (c) GT. The (a) and (c) images were created using Google Earth (version 5.0), 2 February 2009. (b) Was a Quickbird image, August 2009. A digital elevation model was also plotted in (b) and (c).

pressure, precipitation, soil temperature and moisture profile, net radiation, and soil heat flux. The measurements made with these sensors were recorded using data loggers (CR800 at YK, CR23X at AR, CR23XTD at GT, Campbell Scientific Inc.), and the output data were stored at 10-min intervals. All of the data from 2008 and 2009 were used in this study. 
Table 1. Description of the instruments incorporated in the EC, LAS and AWS at each site.

\begin{tabular}{|c|c|c|c|c|c|c|c|}
\hline \multirow[t]{2}{*}{ Instrument } & \multirow[t]{2}{*}{ Variable } & \multicolumn{3}{|c|}{ Sensors } & \multicolumn{3}{|c|}{ Height/Depth (m) } \\
\hline & & YK & AR & GT & YK & AR & GT \\
\hline $\mathrm{EC}$ & $\begin{array}{l}\text { Sensible } \\
\text { heat flux } \\
\text { and Latent } \\
\text { heat flux }\end{array}$ & $\begin{array}{l}\text { CSAT3, } \\
\text { Campbell and } \\
\text { Li7500, } \\
\text { Li-cor }\end{array}$ & $\begin{array}{l}\text { CSAT3, Campbell } \\
\text { and } \mathrm{KH}_{2} \mathrm{O}, \\
\text { Campbell } \\
\text { (11 Mar 2008 } \\
2 \text { Apr 2008) } \\
\text { CSAT3, } \\
\text { Campbell and } \\
\text { Li7500, Li-cor } \\
\text { (10 Jun 2008 } \\
31 \text { Dec 2009) }\end{array}$ & $\begin{array}{l}\text { CSAT3, } \\
\text { Campbell } \\
\text { and Li7500, } \\
\text { Li-cor }\end{array}$ & 2.81 & 3.15 & 20.25 \\
\hline LAS & $\begin{array}{l}\text { Sensible heat } \\
\text { flux }\end{array}$ & & $\begin{array}{l}\text { BLS450, Scintec } \\
\text { (11 Mar 2008 31 Oct 2008, } \\
1 \text { Jan 2009-30 Jun 2009) }\end{array}$ & & & $\begin{array}{r}9.5 \\
(\text { path length } \\
2390 \mathrm{~m})\end{array}$ & \\
\hline \multirow[t]{10}{*}{ AWS } & $\begin{array}{l}\text { Air temperature/ } \\
\text { humidity }\end{array}$ & $\begin{array}{l}\text { HMP45C, } \\
\text { Vaisala }\end{array}$ & $\begin{array}{l}\text { HMP45C, } \\
\text { Vaisala }\end{array}$ & $\begin{array}{l}\text { HMP45C, } \\
\text { Vaisala }\end{array}$ & 3,10 & 2,10 & $2,10,24$ \\
\hline & Wind speed & $\begin{array}{l}\text { 010C-1, } \\
\text { Metone }\end{array}$ & 014A, Metone & $\begin{array}{l}\text { 014A/034B, } \\
\text { Metone }\end{array}$ & 3,10 & 2,10 & $2,10,24$ \\
\hline & $\begin{array}{l}\text { Wind } \\
\text { direction }\end{array}$ & $\begin{array}{l}\text { 020C-1, } \\
\text { Metone }\end{array}$ & 034B, Metone & $\begin{array}{l}\text { 034B, } \\
\text { Metone }\end{array}$ & 10 & 10 & 24 \\
\hline & $\begin{array}{l}\text { Short } \\
\text { wave } \\
\text { radiation }\end{array}$ & $\begin{array}{l}\text { CM3, Kipp } \\
\text { and Zonen }\end{array}$ & PSP, Eppley & $\begin{array}{l}\text { CM3, Kipp } \\
\text { and Zonen }\end{array}$ & 4 & 1.5 & 19.75 \\
\hline & $\begin{array}{l}\text { Long } \\
\text { wave } \\
\text { radiation }\end{array}$ & $\begin{array}{l}\text { CG3, Kipp } \\
\text { and Zonen }\end{array}$ & PIP, Eppley & $\begin{array}{l}\text { CG3, Kipp } \\
\text { and Zonen }\end{array}$ & 4 & 1.5 & 19.75 \\
\hline & $\begin{array}{l}\text { Soil heat } \\
\text { flux }\end{array}$ & $\begin{array}{l}\text { HFP01, } \\
\text { Hukeflux }\end{array}$ & $\begin{array}{l}\text { HFT3, } \\
\text { Campbell }\end{array}$ & $\begin{array}{l}\text { HFP01, } \\
\text { Hukeflux }\end{array}$ & $0.05,0.15$ & $0.05,0.15$ & $0.05,0.15$ \\
\hline & $\begin{array}{l}\text { Soil } \\
\text { temperature }\end{array}$ & $\begin{array}{l}\text { 109, } \\
\text { Campbell }\end{array}$ & $\begin{array}{l}\text { 107, } \\
\text { Campbell }\end{array}$ & $\begin{array}{l}\text { 107, } \\
\text { Campbell }\end{array}$ & $\begin{array}{l}0.1,0.2,0.4 \\
0.8,1.2,1.6\end{array}$ & $\begin{array}{r}0.1,0.2,0.4 \\
0.8,1.2,1.6\end{array}$ & $\begin{array}{r}0.05,0.1,0.2 \\
0.4,0.8,1.2\end{array}$ \\
\hline & $\begin{array}{l}\text { Soil } \\
\text { moisture }\end{array}$ & $\begin{array}{l}\text { CS616, } \\
\text { Campbell }\end{array}$ & $\begin{array}{l}\text { CS616, } \\
\text { Campbell }\end{array}$ & $\begin{array}{l}\text { CS616, } \\
\text { Campbell }\end{array}$ & $\begin{array}{l}0.1,0.2,0.4 \\
0.8,1.2,1.6\end{array}$ & $\begin{array}{r}0.1,0.2,0.4 \\
0.8,1.2,1.6\end{array}$ & $\begin{array}{r}0.05,0.1,0.2 \\
0.4,0.8,1.2\end{array}$ \\
\hline & Air pressure & $\begin{array}{l}\text { CS100, } \\
\text { Campbell }\end{array}$ & $\begin{array}{l}\text { CS105, } \\
\text { Vaisala }\end{array}$ & $\begin{array}{l}\text { CS105, } \\
\text { Vaisala }\end{array}$ & - & - & - \\
\hline & Precipitation & $\begin{array}{l}52202 \\
\text { R. M. Young }\end{array}$ & $\begin{array}{l}\text { TE525, } \\
\text { Campbell }\end{array}$ & $\begin{array}{l}52202 \\
\text { R. M. Young }\end{array}$ & - & - & - \\
\hline \multicolumn{2}{|c|}{ Landscape } & \multicolumn{6}{|c|}{ YK: Cropland (maize, wheat), AR: Alpine meadow, GT: Forest (Qinghai spruce) } \\
\hline \multicolumn{2}{|c|}{ Vegetation Height } & \multicolumn{6}{|c|}{$\begin{array}{l}\text { YK: the maximum height of } 1 \mathrm{~m} \text { for spring wheat, and } 1.8 \mathrm{~m} \text { for maize } \\
\text { AR: the maximum height of } 0.2-0.3 \mathrm{~m} \text { for grass } \\
\text { GT: forest canopy height of } 18-20 \mathrm{~m}\end{array}$} \\
\hline
\end{tabular}

\subsection{Data processing}

In addition to careful instrument maintenance and periodic calibration, high quality data were obtained through rigorous post-processing. The processing of the EC data, the LAS data, the soil surface heat flux, the remote sensing data, and the footprint model are discussed in this section.

\subsubsection{Eddy covariance system}

The EC data processing included spike detection, lag correction of $\mathrm{H}_{2} \mathrm{O} / \mathrm{CO}_{2}$ relative to the vertical wind component, sonic virtual temperature correction, coordinating rotation using the planar fit method, corrections for density fluctuation (WPL-correction), and frequency response correction, etc. The EdiRe software (University of Edinburgh, http:// www.geos.ed.ac.uk/abs/research/micromet/EdiRe) was used for the above corrections. In addition to these processing 
steps, the half-hourly flux data were screened according to the following criteria: (i) data were rejected when the sensor was malfunctioning (e.g., when there was a fault diagnostic signal), (ii) data were rejected when precipitation occurred within $1 \mathrm{~h}$ before and after the collection, (iii) incomplete 30-min data were rejected when the missing ratio was larger than $3 \%$ in the 30-min raw record, and (iv) data were rejected at night when the friction velocity was below $0.1 \mathrm{~m} \mathrm{~s}^{-1}$ (Blanken et al., 1998).

\subsubsection{Large aperture scintillometer}

The LAS system consists of a transmitter and a receiver, the transmitter emits electromagnetic radiation that is scattered by the turbulent atmosphere over a distance of a few kilometers. The structure parameter of the refractive index of air, $C_{n}^{2}\left(\mathrm{~m}^{-2 / 3}\right)$, is calculated from the variance of the natural logarithm of intensity fluctuations $\left(\sigma_{\ln I}^{2}\right)$ by the following equation (Wang et al., 1978):

$C_{n}^{2}=1.12 \sigma_{\operatorname{lnI}}^{2} D^{7 / 3} L^{-3}$

where $D$ is the aperture diameter $(\mathrm{m})$, and $L$ is the path length (m). Strictly speaking, $C_{n}^{2}$ is related to the temperature structure parameter, $C_{T}^{2}\left(\mathrm{~K}^{2} \mathrm{~m}^{-2 / 3}\right)$, the humidity structure parameter, $C_{q}^{2}\left(\mathrm{~kg}^{2} \mathrm{~m}^{-6} \mathrm{~m}^{-2 / 3}\right)$, and a covariant term, $C_{T q}$ $\left(\mathrm{K} \mathrm{kg} \mathrm{m}^{-3} \mathrm{~m}^{-2 / 3}\right)$. The optical scintillometer is more sensitive to variations of temperature than humidity. As a simplification, Wesely (1976) showed that $C_{n}^{2}$ could be related to $C_{T}^{2}$ by

$C_{T}^{2}=C_{n}^{2}\left(\frac{T^{2}}{-7.87 \times 10^{-7} P}\right)^{2}\left(1+\frac{0.03}{\beta}\right)^{-2}$

where $T$ is the air temperature $(\mathrm{K}), P$ is the air pressure $(\mathrm{Pa})$, and $\beta$ is the Bowen ratio. According to the MoninObukhov similarity theory (MOST), the sensible heat flux, $H_{\text {LAS }}\left(\mathrm{W} \mathrm{m}^{-2}\right)$, can be calculated from the following equations:

$$
\begin{aligned}
& \frac{C_{T}^{2}\left(z_{\mathrm{LAS}}-d\right)^{2 / 3}}{T_{*}^{2}}=f_{T}\left(\frac{z_{\mathrm{LAS}}-d}{L_{\mathrm{Ob}}}\right) \\
& H_{\mathrm{LAS}}=\rho_{\mathrm{a}} C_{\mathrm{p}} u_{*} T_{*} \\
& u_{*}=\frac{k_{\mathrm{v}} u}{\ln \left(\frac{z_{u}-d}{z_{0 \mathrm{~m}}}\right)-\Psi_{\mathrm{m}}\left(\frac{z_{u}-d}{L_{\mathrm{Ob}}}\right)+\Psi_{\mathrm{m}}\left(\frac{z_{0 \mathrm{~m}}}{L_{\mathrm{Ob}}}\right)}
\end{aligned}
$$

where $z_{\text {LAS }}$ is the effective height of the LAS (m), $d$ is the zero-plane displacement height $(\mathrm{m}), L_{\mathrm{Ob}}$ is the Obukhov length $(\mathrm{m})$, and $f_{T}$ is the stability function, as previously defined (Andreas, 1988). For unstable conditions (i.e., $\left.L_{\mathrm{Ob}}<0\right), f_{T}=4.9\left[1-6.1\left(\frac{z_{\mathrm{LAS}}-d}{L_{\mathrm{Ob}}}\right)\right]^{-2 / 3}$; for stable conditions (i.e., $L_{\mathrm{Ob}}>0$ ), $f_{T}=4.9\left[1+2.2\left(\frac{z_{\mathrm{LAS}}-d}{L_{\mathrm{Ob}}}\right)^{2 / 3}\right]$.
Eqs. (3-5), $C_{\mathrm{p}}$ is the specific heat capacity of air at a constant pressure $\left(\mathrm{J} \mathrm{kg}^{-1} \mathrm{~K}^{-1}\right), \rho_{\mathrm{a}}$ is the density of air $\left(\mathrm{kg} \mathrm{m}^{-3}\right), u_{*}$ is the friction velocity $\left(\mathrm{m} \mathrm{s}^{-1}\right), T_{*}$ is the temperature scale $(\mathrm{K})$, $k_{\mathrm{V}}$ is the von Kármán constant $(0.40), u$ is the wind speed $\left(\mathrm{m} \mathrm{s}^{-1}\right), z_{u}$ is the measurement height of the wind speed (m), $z_{0 \mathrm{~m}}$ is the aerodynamic roughness length $(\mathrm{m})$, and $\Psi_{\mathrm{m}}$ is the stability correction function for the momentum transfer (Paulson, 1970; Webb, 1970; Businger et al., 1971). The zero-plane displacement height is calculated from the simple relationship between $d$ and the vegetation canopy height, $h_{\mathrm{c}}$ (i.e. $d=\frac{2}{3} h_{\mathrm{c}}$ ), and the aerodynamic roughness length is calculated with EC data based on the method suggested by Yang et al. (2003), which was obtained by minimizing a cost function assuming the aerodynamic roughness length is constant over short period of time (e.g., 10 days).

Four steps were taken to ensure the quality of the LAS data, as follows: (i) we rejected data for $C_{n}^{2}$ beyond the saturation criterion, which was determined according to Ochs and Wilson (1993); the upper limit of the $C_{n}^{2}$ saturation at AR was $7.25 \times 10^{-14} \mathrm{~m}^{-2 / 3}$; (ii) data obtained during periods of precipitation were rejected; (iii) data were rejected when the minimum value of the demodulated signal $(X)$ was less than 50 in the raw data (1-min average time period); and (iv) data were rejected when the sensor was malfunctioning.

Because the scintillometer can only observe the intensity of atmospheric turbulence, it cannot determine the direction of the sensible heat flux. Thus, the difference of the air temperature at two heights (namely, $2 \mathrm{~m}$ and $10 \mathrm{~m}$ at AR) was used to judge the sign of the LAS flux.

\subsubsection{Soil surface heat flux}

The soil surface heat flux is an important component of the surface energy budget. Because the soil heat flux plates were buried at depths of $0.05 \mathrm{~m}$ and $0.15 \mathrm{~m}$ in this study (Table 1), the soil surface heat flux was estimated using the method proposed by Yang and Wang (2008), which is a temperature prediction-correction method based on the thermal exchange equation using the profile of soil temperature and moisture observations, as follows:

$$
G_{z}=G\left(z_{\mathrm{r}}\right)+\int_{z}^{z_{\mathrm{r}}} \frac{\partial C_{v} T(z)}{\partial t} d z
$$

where $G_{z}$ is the soil heat flux $\left(\mathrm{W} \mathrm{m}^{-2}\right)$ at depth $z, t$ is the time (s), $C_{v}$ is the soil heat capacity $\left(\mathrm{J} \mathrm{kg}^{-1} \mathrm{~K}^{-1}\right), T$ is the soil temperature $(\mathrm{K}), z$ is the soil depth $(\mathrm{m})$ (positive downward), and $G\left(z_{\mathrm{r}}\right)$ is the soil heat flux at reference depth $z_{\mathrm{r}}$. In this study, the reference depth, $z_{\mathrm{r}}$, was $1.6,1.6$, and $1.2 \mathrm{~m}$ depth at YK, AR and GT, respectively. Therefore, we assumed $G\left(z_{\mathrm{r}}\right) \approx 0$. 
Given the temperature profile $T\left(z_{i}\right)$, the soil surface heat flux, $G_{0}$, is:

$$
\begin{aligned}
G_{0} & =\frac{1}{\Delta t} \sum_{i=0}^{z_{\mathrm{r}}}\left[c_{v}\left(z_{i}, t+\Delta t\right) T\left(z_{i}, t+\Delta t\right)\right. \\
& \left.-c_{v}\left(z_{i}, t\right) T\left(z_{i}, t\right)\right] \Delta z
\end{aligned}
$$

where $z_{i}$ is the depth of soil layer $i(\mathrm{~m}), \Delta t$ is the time interval (s), and $\Delta z$ is the thickness of a thin layer of the soil (m).

This method constructed the soil temperature profile and then corrected it using the measured soil temperature. By integrating Eq. (7), from the surface to the reference depth, one can obtain the soil surface heat flux. Table 1 lists the measurements of soil temperature and moisture profile in this study. The surface temperature $\left(T_{\mathrm{S}}\right)$ was calculated from measurements of longwave radiation fluxes, that is, $T_{\mathrm{S}}=\left(\frac{R_{L \uparrow}-(1-\varepsilon) R_{L \downarrow}}{\varepsilon \sigma}\right)^{1 / 4}$, where the Stefan-Boltzmann constant $\sigma=5.67 \times 10^{-8} \mathrm{~W} \mathrm{~m}^{-2} \mathrm{~K}^{-4}$, and $R_{L \uparrow}\left(\mathrm{W} \mathrm{m}^{-2}\right)$ and $R_{L \downarrow}\left(\mathrm{W} \mathrm{m}^{-2}\right)$ are the upward and downward longwave radiation components, respectively. The surface emissivity, $\varepsilon$, was given empirically ( 0.987 at YK and AR, and 0.993 at GT) (Wang et al., 2008).

\subsubsection{Footprint model}

The turbulent fluxes obtained from the EC and LAS measurements reflect the influence of the underlying surface on the turbulent exchange (Schmid, 2002). The field of view of these measurements can be well defined by the so-called source area, the sizes and extent of which depend on many factors, such as the measurement height, atmospheric stability, wind speed and direction, and aerodynamic roughness length. It is necessary to determine the source area of the EC and LAS measurements using the footprint model before analyzing the characteristics of the energy and water vapor fluxes.

In this study, we used an Eulerian analytic flux footprint model (Kormann and Meixner, 2001) to obtain the flux footprint of a single point vertical flux measurement, $f\left(x, y, z_{\mathrm{m}}\right)$, as follows:

$f\left(x, y, z_{\mathrm{m}}\right)=D_{y}(x, y) f^{y}\left(x, z_{\mathrm{m}}\right)$

where $x$ is the downwind distance pointing against the average horizontal wind direction, $y$ is the crosswind wind distance, $z_{\mathrm{m}}$ is the measurement height, $f^{y}\left(x, z_{\mathrm{m}}\right)$ is the crosswind integrated footprint, and $D_{y}(x, y)$ is the Gaussian crosswind distribution function of the lateral dispersion. It is worth noting that the observed wind velocity at $z_{\mathrm{m}}$ was used as an input item to gain the model parameters.

For the LAS flux observations, by combining the pathweighting function of the LAS (Meijninger et al., 2002a) with the above point flux footprint model, we deduce the following:

$$
\begin{array}{r}
f_{\mathrm{LAS}}\left(x^{\prime}, y^{\prime}, z_{\mathrm{m}}\right)=\int_{x_{2}}^{x_{1}} W(x) \\
\quad f\left(x-x^{\prime}, y-y^{\prime}, z_{\mathrm{m}}\right) d x
\end{array}
$$

where $W(x)$ is the path-weighting function of the LAS, $x_{1}$ and $x_{2}$ are the locations of the LAS transmitter and receiver, $x$ and $y$ denote the points along the optical length of the LAS, and $x^{\prime}$ and $y^{\prime}$ are the coordinates upwind of each of the points ( $x$ and $y$ ).

To obtain the monthly flux source area of the EC and LAS flux measurements, we determined the monthly footprint by averaging every half-hourly footprint when the sensible heat fluxes were larger than zero. Values that were obtained within the time ranging from 22:00 to 06:00 BST (Beijing standard time) were also excluded. We chose an area of $3 \mathrm{~km} \times 3 \mathrm{~km}$ with a $30 \mathrm{~m}$ resolution as the total calculation area around the measurement point for the EC and the central part of the LAS optical path, respectively. We then set the flux contribution of the chosen total source area at $80 \%$ for each month and $95 \%$ for every $30 \mathrm{~min}$.

\subsubsection{Remote sensing data}

The remote sensing data used in this study included the ASTER (Advanced Spaceborne Thermal Emission and Reflection radiometer) surface temperature product (2B03) and the Landsat TM5 (Thematic Mapper) images. The ASTER surface temperature product was collected on 25 March and 15 July 2008, with an overpass time of 12:30 BST (Beijing standard time). The resolution was $90 \mathrm{~m}$, which was resampled to $30 \mathrm{~m}$. For the Landsat TM5 image, the surface temperature on 21 April and 24 June 2009, were retrieved using the mono-window algorithm (Qin et al., 2001). The overpass time of Landsat was 12:00 BST, and the resolution was resampled from the initial $60 \mathrm{~m}$ to $30 \mathrm{~m}$.

\section{Results and discussion}

\subsection{Source areas of flux measurements}

The source areas of the EC and LAS measurements in January, April, July and October of 2008 at YK, AR and GT (January and April of 2009 at AR) are shown in Fig. 3.

As depicted in Fig. 3, the source areas of EC in January and April were larger than in July and October at YK, and the shape changed with the wind direction during each month. However, the main contributing source area of the EC measurements for each month was within a $180 \mathrm{~m}$ radius of the observation point at $\mathrm{YK}$, and the contribution ratio increased to a maximum approximately $30 \mathrm{~m}$ away from the observation point. At AR, the source area of the EC measurements 

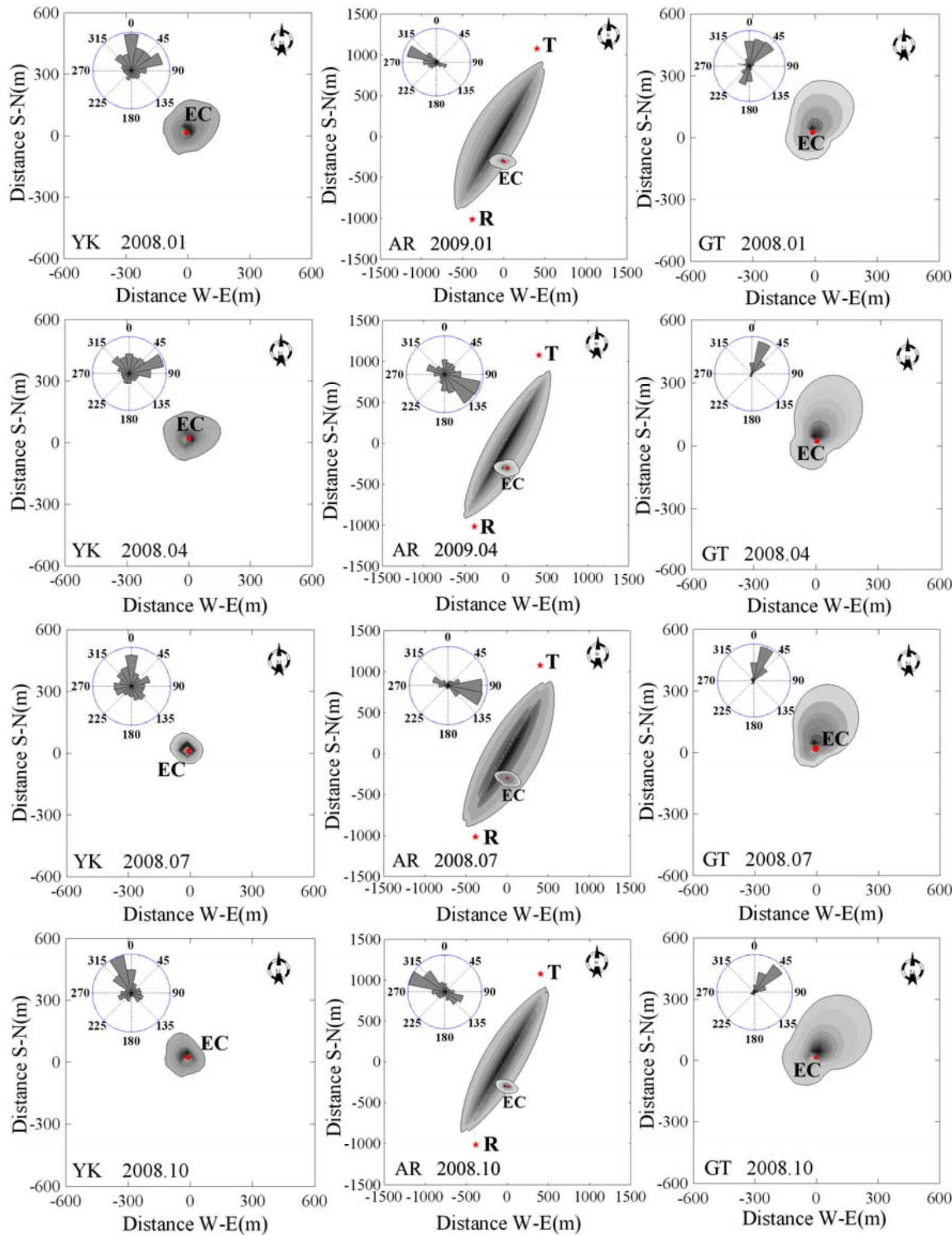

Footprint

High contribution

Low contribution

R LAS Receiver

$\mathrm{T}$ LAS Transmitter

Fig. 3. Source areas of the LAS and EC measurements at the different sites (the source area of $80 \%$ contribution to the measured fluxes). 
were distributed from the southeast to the northwest during each month, and the main contribution area extended approximately $400 \mathrm{~m}$ in the east-west direction and $200 \mathrm{~m}$ across. The contribution ratio reached its maximum approximately $30 \mathrm{~m}$ away from the EC system. At GT, the source areas of EC during each month extended from southwest to northeast, with the main contribution area localized within $460 \mathrm{~m}$ (south-north) and $450 \mathrm{~m}$ (east-west). The source areas for April and October were a little larger than January and July, and the maximum contribution ratio was approximately $50 \mathrm{~m}$ away from the EC system. The source areas of the LAS measurements at AR extended from the northeast to the southwest, with the main contribution source area being approximately $700 \mathrm{~m}$ wide and $2000 \mathrm{~m}$ long.

The source areas of the EC measurements at each site extended along the prevailing wind direction. The source area of the LAS measurements was along its optical path and was typically distributed on both sides of the optical path. The exact shape of the source area primarily depended on the measurement height, the wind direction and the stability of the atmosphere. The different source areas for the EC and LAS represented different land surface characteristics (roughness, thermal and moisture properties) contributing to their measurements, and was the main reason causing the different measured fluxes (see Sect. 3.3). At YK, for example, the prevailing wind directions were north and northeast in January, thus, the main contribution source areas of the EC measurements extended in the same directions. In July, the dominant wind directions were north and west. Therefore, the contributions of the two directions at this time were higher than the other directions. Similar results were observed at the other two sites. At YK, the underlying surface of the source areas of EC consisted mainly of bare soil in January, April and October, and fields of maize interplanted with spring wheat in July. The underlying surface within the source areas of the EC and LAS measurements at AR was alpine meadow, whereas the source areas of EC at GT were covered with forest (Qinghai spruce) (Fig. 2).

\subsection{Seasonal variations of energy balance components}

\subsubsection{Energy balance closure of EC}

To show the energy balance closure at the three sites, the turbulent energy fluxes (the sum of sensible heat flux $H$ and latent heat flux $L E$ ) were plotted against the available energy (net radiation $R_{n}$ minus soil surface heat flux $G_{0}$ ) in Fig. 4, using the half-hourly data obtained during the period from January to December at YK and GT in 2008 and 2009 and the periods from June to December in 2008 and January to December in 2009 at AR. The soil surface heat flux $\left(G_{0}\right)$ was obtained at each site using Eq. (7).

Preservation of the surface energy balance is a theoretical requirement of the first law of thermodynamics. At the surface, turbulent energy fluxes should be equal to the
Table 2. Coefficients of the relationship between $H+L E$ and $R_{n}-$ $G_{0}$, and the EBR at the three sites in 2008 and 2009.

\begin{tabular}{|c|c|c|c|c|c|c|c|c|}
\hline \multirow[t]{2}{*}{ Sites } & \multicolumn{2}{|c|}{$a$} & \multicolumn{2}{|c|}{$b$} & \multicolumn{2}{|c|}{$R^{2}$} & \multicolumn{2}{|c|}{ EBR } \\
\hline & 2008 & 2009 & 2008 & 2009 & 2008 & 2009 & 2008 & 2009 \\
\hline YK & 0.85 & 0.82 & 10.80 & 17.84 & 0.93 & 0.90 & 0.88 & 0.87 \\
\hline AR & 0.86 & 0.73 & 3.64 & 10.36 & 0.89 & 0.88 & 0.89 & 0.85 \\
\hline GT & 0.58 & 0.54 & 36.08 & 41.30 & 0.86 & 0.85 & 0.81 & 0.79 \\
\hline
\end{tabular}

available energy. However, the energy balance has not been observed in most previous experiments. For example, Wilson et al. (2002) evaluated the energy balance closure across 22 sites (50 site-years) in FLUXNET by statistically regressing the turbulent energy fluxes against the available energy and solving for the energy balance ratio (EBR), the ratio of the turbulent energy fluxes to the available energy. Their results showed that the average EBR for all of the cases was 0.84 (ranging from 0.34 to 1.69), and the average EBR was 0.79 when the data with EBR larger than 1 were rejected. This imbalance has also been observed in other experiments (Mauder et al., 2006; Oncley et al., 2007). For the data obtained in the Heihe River Basin, the relationship between $H+L E$ and $R_{n}-G_{0}$ can be expressed by the following equation: $(H+L E)=a\left(R_{n}-G_{0}\right)+b$, where $a$ and $b$ are constants. Coefficients $a, b, R^{2}$ and EBR are shown in Table 2 and Fig. 4. These EBRs for the three sites were similar to values (approximately 70-90\%) previously reported for cropland, grassland and forest surfaces (Meyers and Hollinger, 2004; Twine et al., 2000; Goulden et al., 1997).

As mentioned above, all of the instruments used in this experiment were periodically calibrated and were carefully maintained, and the data were also carefully processed. Thus, instrumental biases are not likely to be the main reason for the observed energy imbalance at the three sites. The soil heat flux was calculated to the surface to consider the soil heat storage. As described in Sect. 2.1, the maximum canopy heights at YK, AR and GT were $1.8 \mathrm{~m}, 0.2-0.3 \mathrm{~m}$ and $20 \mathrm{~m}$, respectively; therefore, the canopy heat storage at the three sites cannot be neglected. According to the studies of Jacobs et al. (2008) and Michiles and Gielow (2008), taking the canopy heat storage into consideration could improve the EBR by $0.5 \%$ and $5 \%$ in middle latitude grasslands and forests (average tree height $23.5 \mathrm{~m}$ ), respectively. The energy balance ratio was within a range of $79 \%$ to $89 \%$ in this study; thus, it seems that there were other reasons for the imbalance. According to recent studies (Mauder et al., 2007b; Foken, 2008; Foken et al., 2010), the secondary circulations and larger eddies cannot be captured by a single station EC measurement, and this may be one of the main causes of the energy imbalance. 

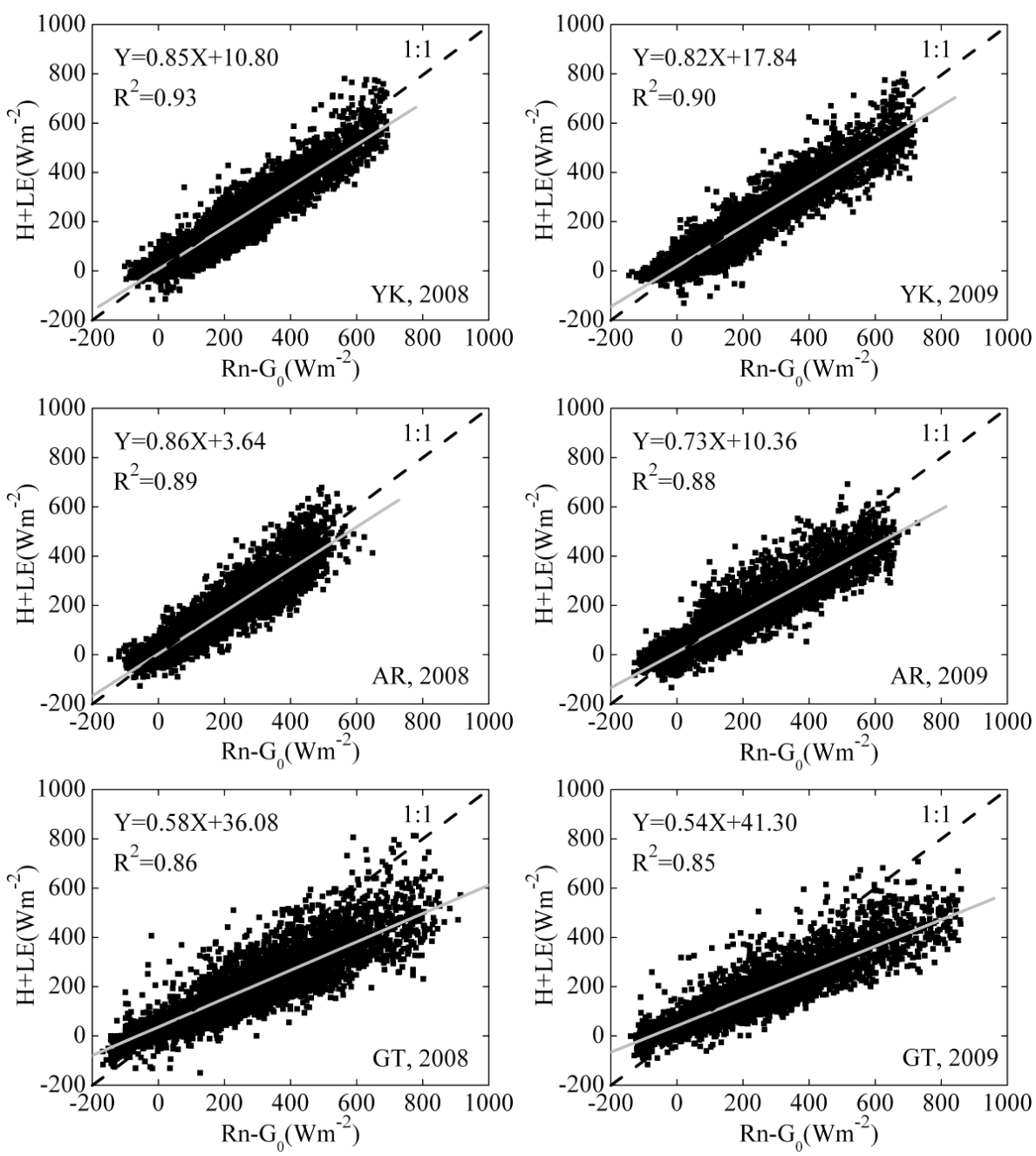

Fig. 4. Relationship between the available energy and the sum of the turbulent energy fluxes based on 30-min EC data at YK, AR and GT in 2008 and 2009.

\subsubsection{Seasonal variation of energy balance components}

To clearly describe the partition of energy into balance components during different seasons, the diurnal patterns of the 30-min averages of $R_{n}, L E, H$ (the sensible heat flux measured by the LAS is denoted by $H_{\text {LAS }}$ ), and $G_{0}$ in January, April, July and October for 2008 (January and April in 2009 at AR) are plotted in Fig. 5. Table 3 summarizes the ratios of $L E, H$, and $G_{0}$ to $R_{n}$, on the monthly average basis (08:0019:00 BST).

Figure 5 and Table 3 show the change in energy partitioning at each site with the season (from $H$ to $L E$ dominated during January to July, and from $L E$ back to $H$ dominated during July to October). The soil surface heat flux accounted for a small proportion of the available energy at each site, especially at GT, where the underlying surface was forest with moss cover. The partitioning of the net radiation into sensible and latent heat fluxes was strongly influenced by changes in vegetative characteristics. Specifically, all of the plants were dormant in January and April, and the surrounding surface in the EC source area was composed of bare soil, withered grassland, and dormant forest at YK, AR and GT, respectively (see Sect. 3.1). Therefore, the sensible heat flux was the main energy consumption in January $\left(H / R_{n}\right.$ at YK $51 \%$; AR 49\%; GT 51\%), whereas the proportions of $L E$ and $G_{0}$ to $R_{n}$ were small. The dominant component of the energy budget was also $H$ in April $\left(H / R_{n}\right.$ at $\mathrm{YK} 36 \%$; AR $47 \%$; GT 55\%).

In July, the underlying surfaces of the EC source areas consisted of maize interplanted with spring wheat, growing grassland and Qinghai spruce at YK, AR and GT, respectively. Thus, the $L E$ increased to account for $74 \%, 58 \%$ and $41 \%$ of $R_{n}$ at YK, AR and GT, respectively. The soil surface heat flux $G_{0}$ accounted for a relatively small proportion at each site (approximately 12\% at YK, $13 \%$ at AR and $0.04 \%$ at GT). One special phenomenon, called the "oasis effect", 

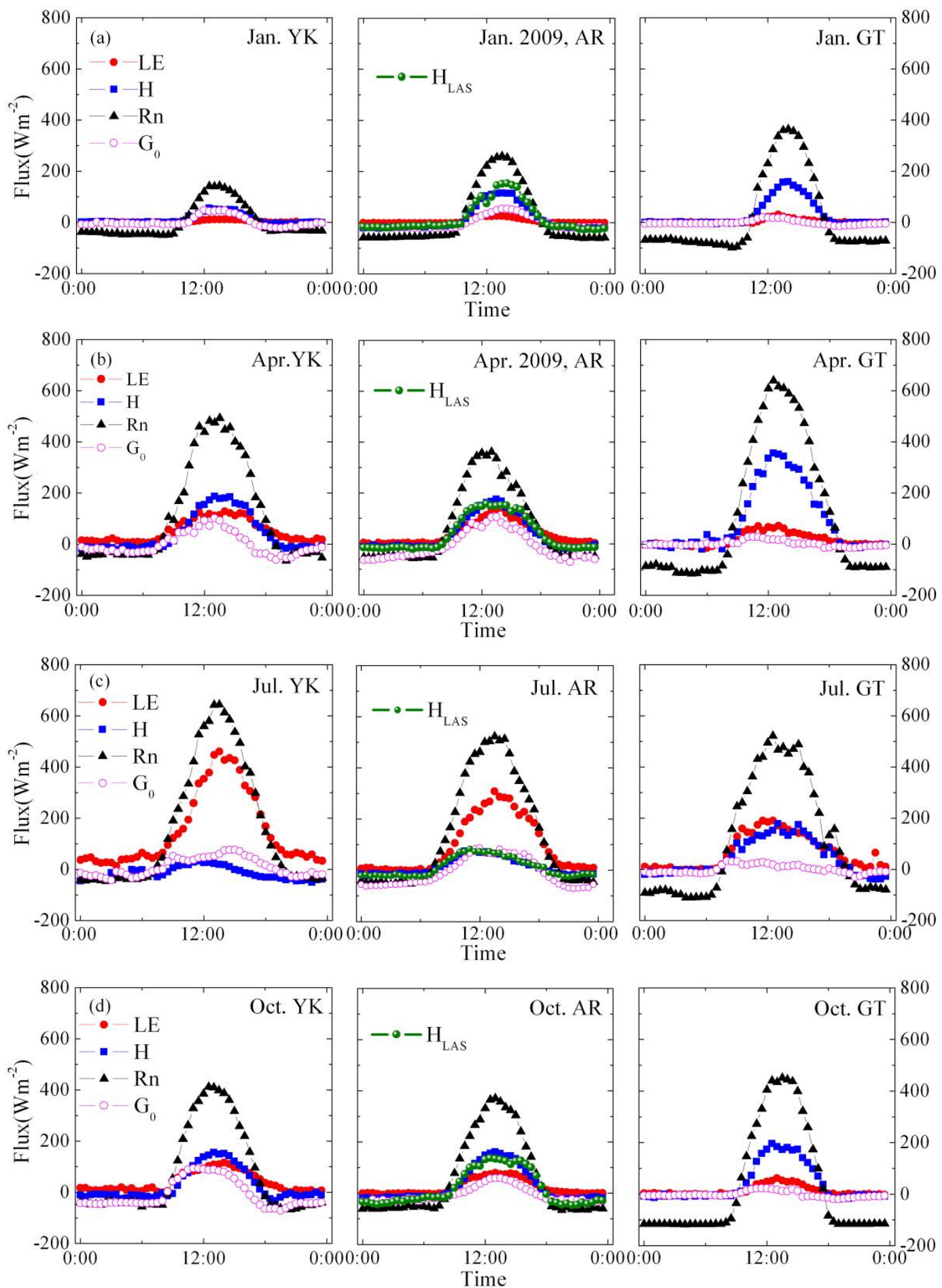

Fig. 5. Seasonal variations in the averaged diurnal course of energy fluxes over different surfaces in 2008 (January and April 2009 at AR) (Beijing standard time, BST).

should be noted for YK in July: (i) $L E$ was the main component and took the largest proportion to $R_{n}(74 \%)$ (Fig. 5c and Table 3); and (ii) $H$ was very small, and even negative in the afternoon when the sensible heat transferred downward and a temperature inversion occurred. This phenomenon is consistent with the results obtained in the Heihe River Basin by Wang et al. (1999). YK was located in the center of an oasis surrounded by Gobi $(7 \mathrm{~km}$ away from the site, see Fig. 2a), and the "oasis effect" was distinctly observed on clear days in summer. 
Table 3. Ratios of the monthly $L E, H, G_{0}$ to $R_{n}$ during different seasons at the three sites in 2008 (08:00-19:00 BST; January and April 2009 at AR; values in the bracket are $H_{\mathrm{LAS}} / R_{n}$ ).

\begin{tabular}{llclc}
\hline Sites & Date & $L E / R_{n}$ & $H / R_{n}$ & $G_{0} / R_{n}$ \\
\hline YK & Jan & 0.13 & 0.51 & 0.28 \\
& Apr & 0.32 & 0.36 & 0.10 \\
& Jul & 0.74 & 0.002 & 0.12 \\
& Oct & 0.36 & 0.35 & 0.16 \\
\hline AR & Jan & 0.12 & $0.49(0.61)$ & 0.18 \\
& Apr & 0.39 & $0.47(0.51)$ & 0.19 \\
& Jul & 0.58 & $0.13(0.15)$ & 0.13 \\
& Oct & 0.26 & $0.43(0.41)$ & 0.09 \\
\hline GT & Jan & 0.06 & 0.51 & 0.03 \\
& Apr & 0.11 & 0.55 & 0.02 \\
& Jul & 0.41 & 0.34 & 0.04 \\
& Oct & 0.14 & 0.48 & 0.02 \\
\hline
\end{tabular}

In October, the underlying surfaces in the EC source areas appeared to be almost the same as in April. The $L E$ was also small at AR and GT, and the $H / R_{n}$ was $43 \%$ at $\mathrm{AR}$ and $48 \%$ at GT. Although the crops had been harvested at YK, because of the application of autumn irrigation (post-harvest irrigation), the $L E$ was still the main term in the energy budget, accounting for $36 \%$ of $R_{n}$. These results indicate that the surface energy budget at each site was mainly determined by local meteorological events, vegetative conditions and soil water content in the source area of the flux measurements. For example, the $L E$ at YK was much higher than at the other two sites during the growing season because of the irrigation.

Due to the energy imbalance, $\left(L E+H+G_{0}\right) / R_{n}$ did not equal 1 at the three sites (Table 3 ). Some causes of the energy imbalance are described in Sect. 3.2.1. Actually, the energy imbalance of the EC occurred not only for the whole period but also for a specific observation period.

The sensible heat flux measured with the LAS $\left(H_{\mathrm{LAS}}\right)$ also exhibited a significant seasonal variation at AR. The underlying surface of the LAS source area was withered grassland in January, April and October and covered with growing grass in July (see Sect. 3.1). The ratios of $H_{\text {LAS }}$ to $R_{n}$ were $61 \%$, $51 \%, 15 \%$, and $41 \%$ in January, April, July and October, respectively (Table 3). Although the tendency and magnitude of the sensible heat fluxes measured by LAS and EC were similar, the $H_{\text {LAS }}$ was slightly higher than the $H_{\mathrm{EC}}$ during unstable conditions in most of the cases, and some explanations will be provided in the next section.

\subsection{Comparison of the sensible heat fluxes derived from LAS and EC}

The sensible heat flux was measured with LAS directly, whereas the latent heat flux was estimated from the energy

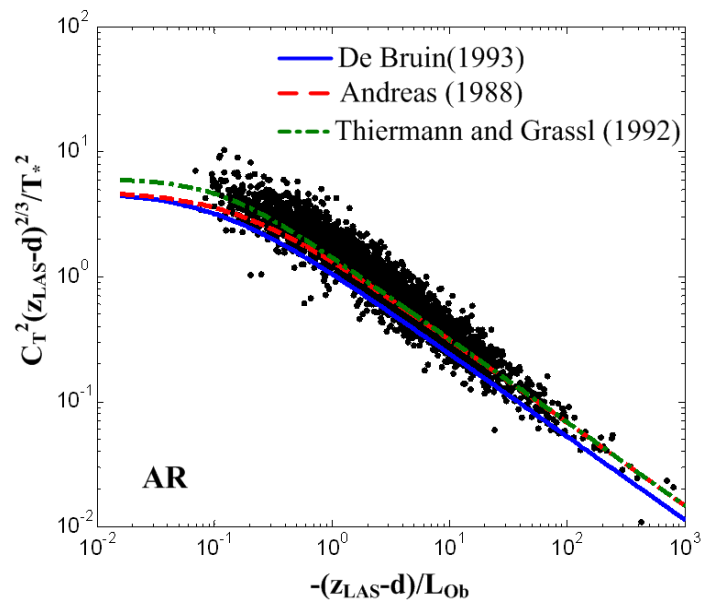

Fig. 6. Observed values of $C_{T}^{2}\left(z_{\text {LAS }}-d\right)^{2 / 3} / T_{*}^{2}$ were plotted against $\left(z_{\mathrm{LAS}}-d\right) / L_{\mathrm{ob}}$ under unstable conditions for the entire dataset (11 March to 31 October 2008, and 1 January to 30 June 2009 , 30-min, $H_{\text {LAS }}$ and $H_{\mathrm{EC}}>50 \mathrm{~W} \mathrm{~m}^{-2}$ ).

balance equation. To reduce possible errors, only the sensible heat fluxes measured with EC and LAS are compared and discussed in this section.

The LAS data processing steps were introduced in Sect. 2.2.2, to ascertain whether the $C_{T}^{2}$ from the LAS behaved according to MOST at AR. The observed values of $C_{T}^{2}\left(z_{\mathrm{LAS}}-d\right)^{2 / 3} / T_{*}^{2}$ were plotted against $\left(z_{\mathrm{LAS}}-d\right) / L_{\mathrm{Ob}}$ in Fig. 6 for the entire selected data set. The values of $T_{*}$ and $L_{\mathrm{Ob}}$ were taken from the EC measurements together with the scaling curves described by De Bruin et al. (1993), Andreas (1988) and Thiermann and Grassl (1992). Figure 6 demonstrates that these points follow the shape of the universal functions. This result also implies that the MOST relationship (Eq. 3) was fully applicable at AR.

The data for the period from 11 March to 31October 2008, and from 1 January to 30 June 2009, were used for this analysis, and the sensible heat fluxes measured by EC $\left(H_{\mathrm{EC}}\right)$ and LAS $\left(H_{\text {LAS }}\right)$ were compared. The results shown in Fig. 7 are only for when $H_{\mathrm{EC}}$ and $H_{\mathrm{LAS}}$ were larger than $50 \mathrm{~W} \mathrm{~m}^{-2}$. Figure 7 shows that the $H_{\mathrm{LAS}}$ was consistent with the $H_{\mathrm{EC}}$ ( $R^{2}=0.65$, for data points $n=3575$ ), but the $H_{\text {LAS }}$ was generally larger than the $H_{\mathrm{EC}}$ (overestimated by $13 \%$ ).

The reasons for such differences between the sensible heat fluxes measured with LAS and EC have been investigated by many researchers. Schüttemeyer et al. (2006) have found that the heterogeneity of the underlying surface caused the differences between the LAS and EC measurements in a mixed vegetation area. Ezzahar et al. (2007) have suggested that the differences between the two measurements could be explained by differences in terms of the source areas of the LAS and EC and the closure failure of the energy balance of the EC. Su et al. (2009) have proposed that the difference between the two measurements may be attributed to the sensitivity of the $H_{\text {LAS }}$ to the aerodynamic roughness length 


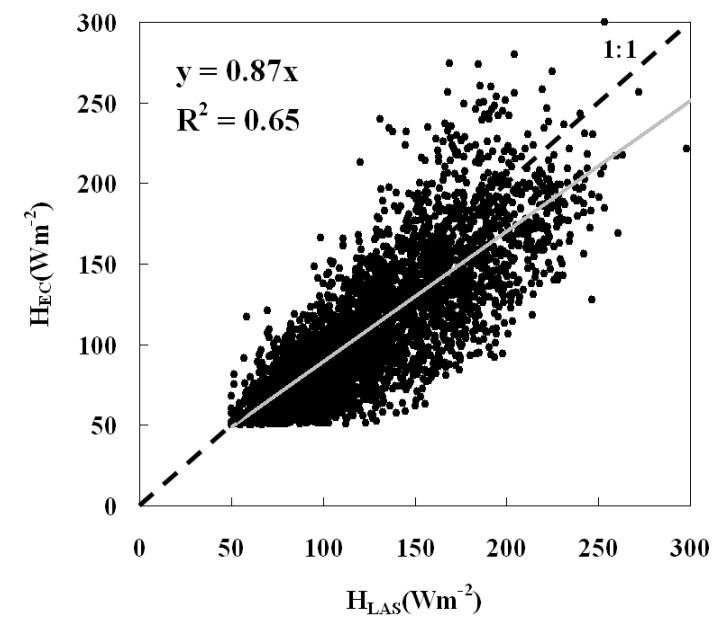

Fig. 7. Comparison of $H_{\mathrm{LAS}}$ and $H_{\mathrm{EC}}$ at $\mathrm{AR}$ when $H_{\mathrm{LAS}}$ and $H_{\mathrm{EC}}>50 \mathrm{~W} \mathrm{~m}^{-2}$ (11 March to 31 October 2008, and 1 January to 30 June 2009, 30-min).

and different footprints. The EBR at AR was $0.89 / 0.85$ in 2008/2009 (see Sect. 3.2.1). To evaluate the influence of the energy imbalance on the difference between the $H_{\mathrm{EC}}$ and $H_{\mathrm{LAS}}$, the scatter plots for EBR and $H_{\mathrm{EC}} / H_{\mathrm{LAS}}$ at AR on a 30-min basis were shown in Fig. 8, with the result that the ratio generally increased with increased EBR, and $H_{\mathrm{EC}}$ approached $H_{\text {LAS. }}$. That is, when the EBR increased, the values of $H_{\mathrm{EC}}$ were closer to $H_{\mathrm{LAS}}$. When the EBR was small, the values of $H_{\mathrm{EC}}$ were notably smaller than $H_{\mathrm{LAS}}$, especially when the EBR was less than 0.75 . However, in the EBR range between 0.75 and 1 , most of the values of $H_{\mathrm{EC}} / H_{\mathrm{LAS}}$ were distributed around one. When their EBRs were larger than 0.75, these points were plotted in Fig. 9, which reveals that the $H_{\mathrm{EC}}$ and $H_{\mathrm{LAS}}$ were much closer to each other, with only a $6 \%$ difference $\left(R^{2}=0.67, n=1202\right)$. The average EBR in Fig. 7 is 0.73, whereas it is 0.86 in Fig. 9. A comparison of Figs. 7 and 9 demonstrates that the energy imbalance of the EC was one of the main causes of the difference between the $H_{\mathrm{EC}}$ and $H_{\mathrm{LAS}}$ at $\mathrm{AR}$.

However, there seem to be other causes of the difference between $H_{\mathrm{EC}}$ and $H_{\mathrm{LAS}}$. Hoedjes et al. (2007) have found that radiative surface temperatures obtained from thermal infrared satellite imagery can provide a good indication of the degree of heterogeneity within the experimental area and can be used to identify the differences between the LAS and EC measurements of the sensible heat fluxes. In the present study, the surface temperatures $\left(T_{\mathrm{s}}\right)$ from four satellite images were used to further analyze the reasons for the difference between the $H_{\mathrm{EC}}$ and $H_{\mathrm{LAS}}$; namely, two ASTER images (25 March and 15 July 2008) and two TM images (21 April and 24 June 2009). The processing steps of these images are described in Sect. 2.2.5. The distribution of the surface temperature measured by the ASTER and TM over the source areas of the LAS and EC are shown in Fig. 10.

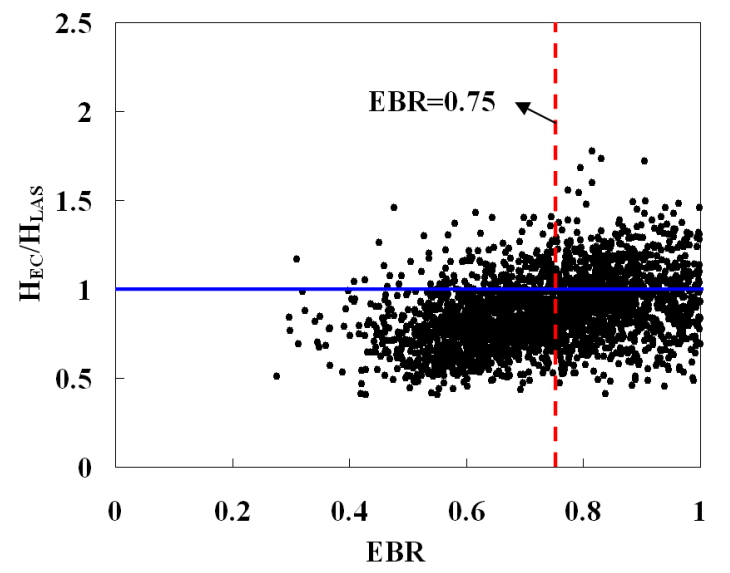

Fig. 8. $H_{\mathrm{EC}} / H_{\mathrm{LAS}}$ scatters according to the Energy Balance closure Ratio (EBR) in the 30-min data at AR when $H_{\mathrm{LAS}}$ and $H_{\mathrm{EC}}>50 \mathrm{~W} \mathrm{~m}^{-2}$ (11 March to 31 October 2008, and 1 January to 30 June 2009 , 30-min).

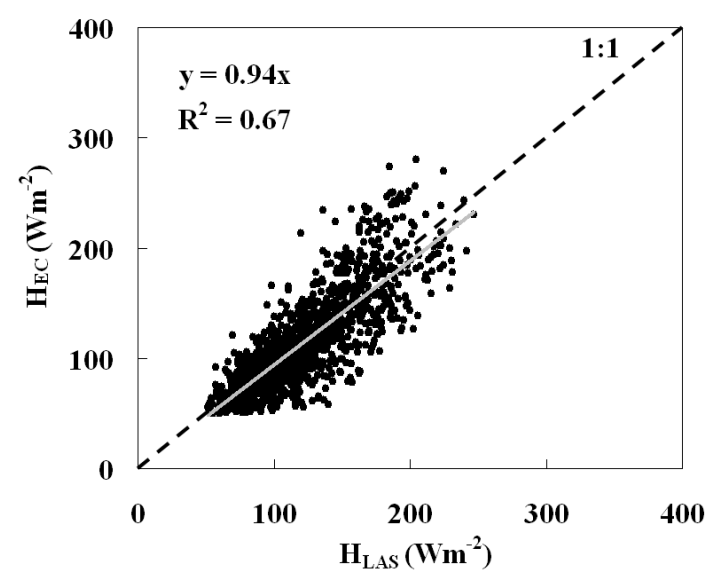

Fig. 9. Comparison of $H_{\mathrm{LAS}}$ and $H_{\mathrm{EC}}$ at $\mathrm{AR}$ when the $H_{\mathrm{LAS}}$ and $H_{\mathrm{EC}}>50 \mathrm{~W} \mathrm{~m}^{-2}$ and EBR $>0.75$ (11 March to 31 October 2008, and 1 January to 30 June 2009, 30-min).

The standard deviation of the surface temperatures in the non-overlapping source area $\left(\operatorname{Std}_{-} T_{\mathrm{S}}\right)$ at the satellite passing time was chosen as an indicator reflecting the heterogeneity of the underlying surface, and $\operatorname{Std}_{-} T_{\mathrm{S}}$ was calculated from $\operatorname{Std}_{-} T_{\mathrm{S}}=\sqrt{\left(\frac{1}{n-1} \sum_{i=1}^{n}\left(T_{\mathrm{s} i}-\overline{T_{\mathrm{S}}}\right)^{2}\right)}$, where $T_{\mathrm{s} i}$ and $\overline{T_{\mathrm{S}}}$ are the surface temperature of pixel $i$ and its average within the nonoverlapping source area, respectively, and $n$ is the total number of pixels. The normalized relative weights of the EC and LAS measurements averaged over the overlapping source area (Ave_RW) were chosen to quantify the differences between the source areas of the LAS and EC. Ave_RW was defined as Ave_RW $=\frac{1}{2}\left(\sum_{i=1}^{m} F P_{\mathrm{LAS} i}+\sum_{i=1}^{m} F P_{\mathrm{EC} i}\right)$, where $F P_{\mathrm{LAS} i}$ and $F P_{\mathrm{EC} i}$ are the normalized footprints of the $\mathrm{EC}$ and LAS measurements of grid $i$ within the overlapping 

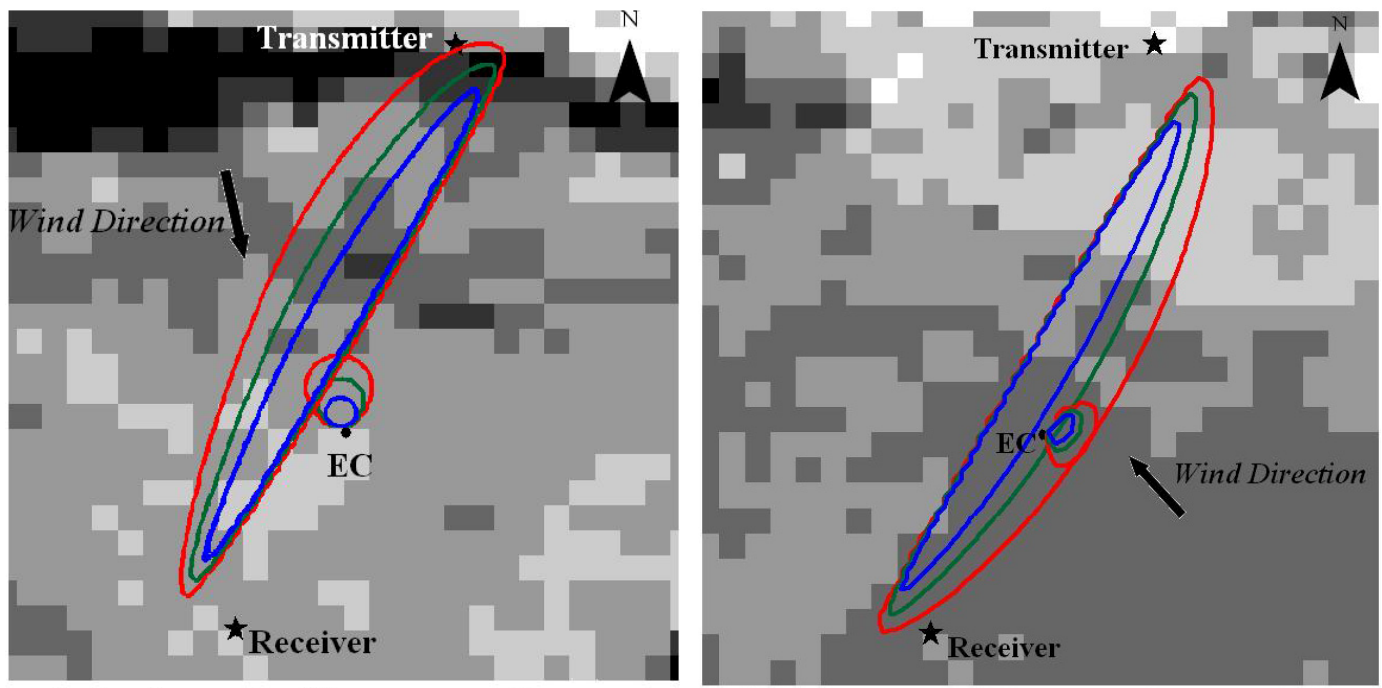

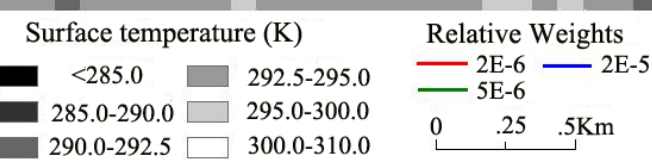

(a)

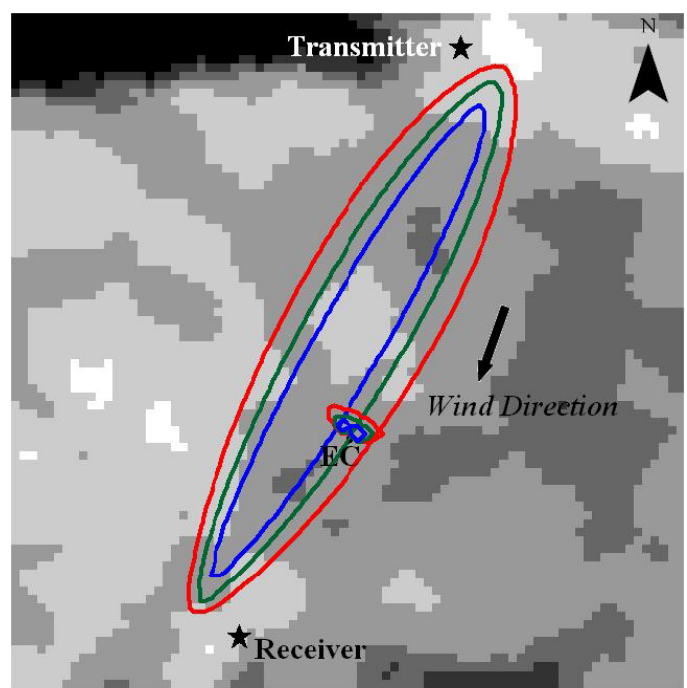

Surface temperature $(\mathrm{K})$
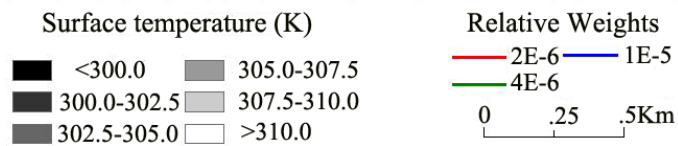

(c)

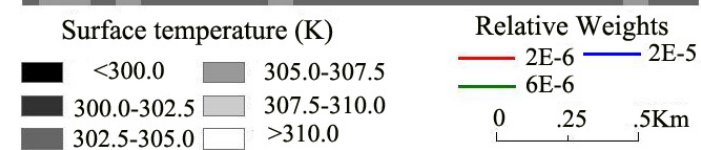

(b)

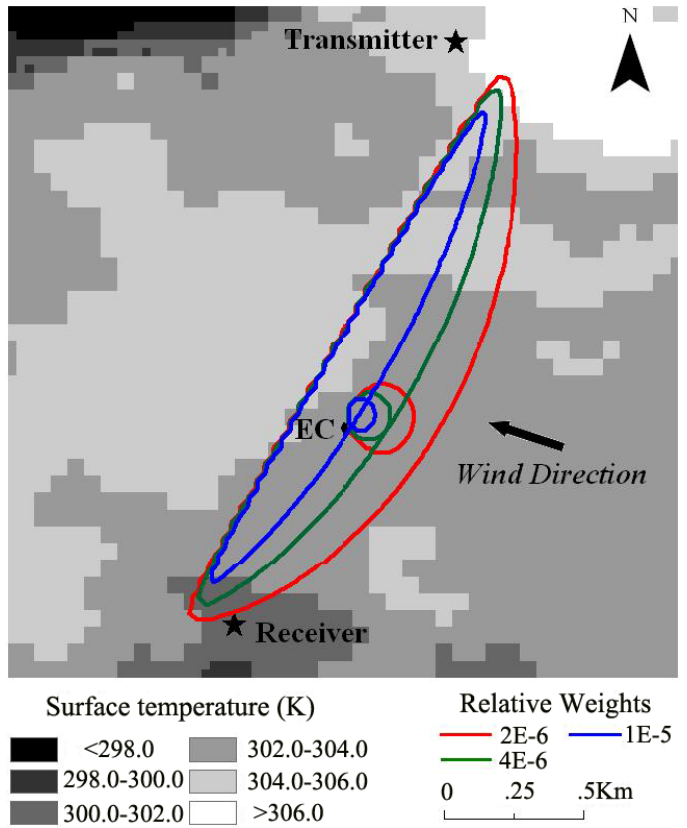

(d)

Fig. 10. Distribution of the surface temperature measured by ASTER and TM passing time over the source areas of the EC and LAS (a) 25 March 2008, ASTER; (b) 15 July 2008, ASTER; (c) 21 April 2009, TM; (d) 24 June 2009, TM (source area of 95\% contribution to the measured fluxes).

source area, respectively, and $m$ is the number of grids within the overlapping source area. Generally, when the source area of the LAS measurements is coincident with that of the EC measurements, the Ave_RW is equal to 1. That is, as the Ave_RW value approaches to 1, the degree of overlap between the source areas of the LAS and EC measurements becomes larger. Table 4 shows the relationships among the differences between EC and LAS measurements $\left(H_{\mathrm{EC}} / H_{\mathrm{LAS}}\right)$, the energy closure ratio (EBR), the degree of overlap between the source areas of the LAS and EC 
Table 4. Relationships among the differences of the EC and LAS measurements, the energy closure ratio of the EC, the degree of overlap between the source areas of the LAS and EC measurements, and the heterogeneity of the underlying surface at the satellite passing time $\left(H_{\mathrm{EC}} / H_{\mathrm{LAS}}\right.$ : the ratio between the sensible heat fluxes measured by the EC and LAS; EBR: energy balance ratio; Ave_RW: the average relative weights of the EC and LAS in the overlapping source area; $\operatorname{Std}_{-} T_{\mathrm{S}}$ : the standard deviation of surface temperature in non-overlapping source area).

\begin{tabular}{lcclc}
\hline Date & $H_{\text {EC }} / H_{\text {LAS }}$ & EBR & Ave_RW & Std_$_{-} T_{\mathrm{S}}(\mathrm{K})$ \\
\hline 25 Mar 2008 & 1.17 & 0.81 & 0.001 & 2.16 \\
15 Jul 2008 & 1.04 & 0.99 & 0.50 & 1.98 \\
21 Apr 2009 & 1.06 & 0.83 & 0.47 & 1.08 \\
24 Jun 2009 & 0.98 & 0.89 & 0.51 & 0.93 \\
\hline
\end{tabular}

measurements (Ave_RW), and the heterogeneity of the underlying surface $\left(\operatorname{Std}_{-} T_{\mathrm{S}}\right)$ at the satellite passing time. The largest ratio of $H_{\mathrm{EC}} / H_{\mathrm{LAS}}$ appeared on 25 March in 2008, with the smallest EBR, a minuscule Ave_RW and the largest Std_ $T_{\mathrm{S}}$ among the four days. The smallest $H_{\mathrm{EC}} / H_{\mathrm{LAS}}$ appeared on 24 June in 2009, with the corresponding smallest Std_ $T_{\mathrm{S}}$, the largest Ave_RW, and the second largest EBR during the four days. This result indicates that the differences between the EC and LAS measurements $\left(H_{\mathrm{EC}} / H_{\mathrm{LAS}}\right)$ can be explained by the energy closure ratio of the EC (EBR), the degree of overlap between the source areas of the LAS and EC measurements (Ave_RW), and the heterogeneity of the underlying surface $\left(\operatorname{Std}_{-} T_{\mathrm{S}}\right)$. All of the three factors have an effect on the differences between $H_{\mathrm{EC}}$ and $H_{\mathrm{LAS}}$, and their effects were coupled with each other. Taking 25 March 2008, and 21 April and 24 June 2009 as examples, similar EBR values were observed on each of the three days; the differences between the $H_{\mathrm{EC}}$ and $H_{\mathrm{LAS}}$ increased with the decreasing Ave_RW and increasing $\operatorname{Std}_{-} T_{\mathrm{S}}$. Comparing 24 June 2009 and 15 July 2008, when the Ave_RW on these two days was very close to each other, the difference of the EBR and $\operatorname{Std} \_T_{\mathrm{S}}$ led to the discrepancy of the $H_{\mathrm{EC}} / H_{\mathrm{LAS}}$.

From these analyses, we conclude that the differences between the sensible heat fluxes derived from the LAS and EC at AR were caused by the energy imbalance of the EC, the heterogeneity of the underlying surfaces, and the difference between the source areas of the EC and LAS measurements.

\section{Conclusions}

In this study, we analyzed the seasonal variations of the energy balance components at YK (irrigated cropland), AR (alpine meadow), and GT (spruce forest) based on measurements made by EC and LAS in the Heihe River Basin, China. We also determined the source areas of the EC and LAS for each site and discussed the factors causing the differences between the sensible heat fluxes measured by EC and LAS at AR.

The source areas of the EC measurements differed significantly from site to site, and the main contribution areas were within a radius of $250 \mathrm{~m}$. The main contribution area for the LAS extended along a path approximately $2000 \mathrm{~m}$ long and $700 \mathrm{~m}$ wide at AR. The surface characteristics in the source areas at the three sites changed with time and had a large influence on the surface energy budget.

The sensible heat flux was the main term of the heat budget at the three sites during the dormant season. During the growing season, however, the latent heat flux was the main term, and an obvious "oasis effect" was observed at YK.

We compared the differences between the sensible heat fluxes measured by the LAS and EC systems at AR in grassland. The results showed that the sensible heat flux measured by the LAS were, on average, larger than those measured by the EC, especially when the EBR was smaller than 0.75 . The thermal infrared satellite images in combination with a footprint model were used to indicate the heterogeneity within the non-overlapping source area between the LAS and EC, and the overlapping ratio was used to reflect the difference between the source areas of the LAS and EC. The results of this study show that the difference between the sensible heat fluxes measured by the LAS and EC systems (in general, the values of the $H_{\mathrm{LAS}}$ were larger than the $H_{\mathrm{EC}}$ ) at AR can be explained by the energy imbalance of the EC, the heterogeneity of the underlying surfaces, and the differences between the source areas of the EC and LAS measurements. The LAS might be able to close the surface energy balance better than the EC method (Foken et al., 2010).

Acknowledgements. The data used in the paper are obtained from the Watershed Allied Telemetry Experimental Research, which is jointly supported by the Special Research Foundation of the Public Benefit Industry (GYHY200706046), National Natural Science Foundation of China (40971194 and 40875006), the Chinese state key basic research project (2007CB714400) and the Chinese academy of sciences action plan for west development program (KZCX2-XB2-09). The ASTER data used in the paper are provided by Shunlin Liang. We thank three reviewers for their valuable comments that greatly improved the presentation of this paper.

Edited by: X. Li 


\section{References}

Andreas, E. L.: Estimating $C_{n}^{2}$ over snow and sea ice from meteorological data, J. Opt. Soc. Am., 5, 481-495, 1988.

Aubinet, M., Grelle, A., Ibrom, A., Rannik, U., Moncrieff, J., Foken, T., Kowalski, A. S., Martin, P. H., Berbigier, P., Bernhofer, Ch., Clement, R., Elbers, J., Granier, A., Grünwald, T., Morgenstern, K., Pilegaard, K., Rebmann, C., Snijders, W., Valentini, R., and Vesala, T.: Estimates of the annual net carbon and water exchange of European forests: the EUROFLUX methodology, Adv. Ecol. Res., 30, 113-174, 2000.

Baldocchi, D. D., Vogel, C. A., and Hall, B.: Seasonal variation of carbon dioxide exchange rates above and below a boreal jack pine forest, Agr. Forest. Meteorol., 83, 147-170, 1997.

Blanken, P. D., Black, T. A., Neumann, H. H., Hartog, C. D., Yang, P. C., Nesic, Z., Staebler, R., Chen, W., and Novak, M. D.: Turbulence flux measurements above and below the overstory of a boreal aspen forest, Bound.-Lay. Meteorol., 89, 109-140, 1998.

Businger, J. A., Wyngaard, J. C., Izumi, Y., and Bradley, E. F.: Flux profile relationships in the atmospheric surface layer, J. Atmos. Sci., 28, 181-189, 1971.

Cava, D., Contini, D., Donateo, A., and Martano, P.: Analysis of short-term closure of the surface energy balance above short vegetation, Agr. Forest. Meteorol., 148, 82-93, 2008.

De Bruin, H. A. R., Kohsiek, W., and v. d. Hurk, B. J. J. M.: A verification of some methods to determine the fluxes of momentum, sensible heat and water vapor using standard deviation and structure parameter of scalar meteorological quantities, Bound.-Lay. Meteorol., 63, 231-257, 1993.

Ezzahar, J., Chehbouni, A., Hoedjes, J. C. B., Er-Raki, S., Chehbouni, Ah., Boulet, G., Bonnefond, J. M., and De Bruin, H. A. R.: The use of the scintillation technique for monitoring seasonal water consumption of olive orchards in a semi-arid region, Agr. Water Manage., 89, 173-184, 2007.

Finnigan, J. J., Clement, R., Malhi, Y., Leuning, R., and Cleugh, H. A.: A reevaluation of long-term flux measurement techniques part I: averaging and coordinate rotation, Bound.-Lay. Meteorol., 107, 1-48, 2003.

Foken, T.: The energy balance closure problem: an overview, Ecol. Appl., 18(6), 1351-1367, 2008.

Foken, T., Mauder, M., Liebethal, C., Wimmer, F., Beyrich, F., Leps, J. P., Raasch, S., De Bruin, H. A. R., Meijninger, W. M. L., and Bange, J.: Energy balance closure for the LITFASS-2003 experiment, Theor. Appl. Climatol., 101, 149-160, 2010.

Goulden, M. L., Daube, B. C., Fan, S. M., Sutton, D. J., Bazzaz, A., Munger, J. W., and Wofsy, S. C.: Physiological responses of a black spruce to weather, J. Geophys. Res., 102(D24), 2898728996, 1997.

Hammerle, A., Haslwanter, A., Schmitt, M., Bahn, M., Tappeiner, U., Cernusca, A., and Wohlfahrt, G.: Eddy covariance measurements of carbon dioxide, latent and sensible energy fluxes above a meadow and a mountain slope, Bound.-Lay. Meteorol., 122, 397-416, 2007.

Hartogensis, O. K., Watts, C. J., Rodriguez, J. C., and De Bruin, H. A. R.: Derivation of an effective height for scintillometers: La Poza experiment in Northwest Mexico, J. Hydrometeorol., 4, 915-927, 2003.

Hiller, R., Zeeman, M. J., and Eugster, W.: Eddy-covariance flux measurements in the complex terrain of an alpine valley in Switzerland, Bound.-Lay. Meteorol., 127, 449-467, 2008.
Hoedjes, J. C. B., Zuurbier, R. M., and Watts, C. J.: Large aperture scintillometer used over a homogeneous irrigated area, partly affected by regional advection, Bound.-Lay. Meteorol., 105, 99117, 2002.

Hoedjes, J. C. B., Chehbouni, A., Ezzahar, J., Escadafal, R., and De Bruin, H. A. R.: Comparison of large aperture scintillometer and eddy covariance measurements: Can thermal infrared data be used to capture footprint-induced differences, J. Hydrometeorol., 8, 144-159, 2007.

Jacobs, A. F. G., Heusinkveld, B. G., and Holtslag, A. A. M.: Towards closing the surface energy budget of a mid-latitude Grassland, Bound.-Lay. Meteorol., 126, 125-136, 2008.

Kanda, M., Inagaki, A., Letzel, M. O., Raasch, S., and Watanabe, T.: LES study of the energy imbalance problem with eddy covariance fluxes, Bound.-Lay. Meteorol., 110, 381-404, 2004.

Kormann, R. and Meixner, F. X.: An analytic footprint model for neutral stratification, Bound.-Lay. Meteorol., 99, 207-224, 2001.

Li, X., Li, X. W., Li, Z. Y., Ma, M. G., Wang, J., Xiao, Q., Liu, Q., Che, T., Chen, E. X., Yan, G. J., Hu, Z. Y., Zhang, L. X., Chu, R. Z., Su, P. X., Liu, Q. H., Liu, S. M., Wang, J. D., Niu, Z., Chen, Y., Jin, R., Wang, W. Z., Ran, Y. H., Xin, X. Z., and Ren, H. Z.: Watershed allied telemetry experimental research, J. Geophys. Res.-Atmos., 114, D22103, doi:10.1029/2008JD011590, 2009.

Li, X., Li, X. W., Roth, K., Menenti, M., and Wagner, W.: Preface "Observing and modeling the catchment scale water cycle", Hydrol. Earth Syst. Sci., 15, 597-601, doi:10.5194/hess-15-5972011, 2011.

Mauder, M., Liebethal, C., Göckede, M., Leps, J. P., Beyrich, F., and Foken, T.: Processing and quality control of flux data during LITFASS-2003, Bound.-Lay. Meteorol., 121, 67-88, 2006.

Mauder, M., Oncley, S. P., Vogt, R., Weidinger, T., Ribeiro, L., Bernhofer, C., Foken, T., Kohsiek, W., De Bruin, H. A. R., and Liu, H. P.: The energy balance experiment EBEX-2000, Part II: Intercomparison of eddy-covariance sensors and post-field data processing methods, Bound.-Lay. Meteorol., 123, 29-54, 2007a.

Mauder, M., Desjardins, R. L., and MacPherson, I.: Scale analysis of airborne flux measurements over heterogeneous terrain in a boreal ecosystem, J. Geophys. Res., 112, D13112, doi:10.1029/2006JD008133, 2007b.

Mauder, M., Desjardins, R. L., Pattey, E., Gao, Z., and van Haarlem, R.: Measurement of the Sensible Eddy Heat Flux Based on Spatial Averaging of Continuous Ground-Based Observations, Bound.-Lay. Meteorol., 128, 151-172, 2008.

McAneney, K. J., Green, A. E., and Astill, M. S.: Large aperture scintillometry: The homogeneous case, Agr. Forest Meteorol., 76, 149-162, 1995.

Meijninger, W. M. L., Hartogensis, O. K., Kohsiek, W., Hoedjes, J. C. B., Zuurbier, R. M., and De Bruin, H. A. R.: Determination of the area-averaged sensible heat flux with a large aperture scintillometer over a heterogeneous surface- Flevoland field experiment, Bound.-Lay. Meteorol., 105, 37-62, 2002a.

Meijninger, W. M. L., Green, A. E., Hartogensis, O. K., Kohsiek, W., Hoedjes, C. B., Zuurbier, R. M., and De Bruin, H. A. R.: Determination of area-averaged water vapour fluxes with large aperture and radio wave scintillometers over a heterogeneous surfaceFlevoland field experiment, Bound.-Lay. Meteorol., 105, 63-83, 2002b. 
Meyers, T. P. and Hollinger, S. E.: An assessment of storage terms in the surface energy balance of maize and soybean, Agr. Forest Meteorol., 125, 105-115, 2004.

Michiles, A. A. S. and Gielow, R.: Above-ground thermal energy storage rates, trunk heat fluxes and surface energy balance in a central Amazonian rainforest, Agr. Forest Meteorol., 148, 917930, 2008.

Moene, A. F., Beyrich, F., and Hartogensis, O. K.: Developments in scintillometry, B. Am. Meteorol. Soc., 90, 694-698, 2009.

Ochs, G. R. and Wilson, J. J.: A second-generation large aperture scintillometer, NOAA Tech. Memor. ERL ETL-232, NOAA Environmental Research Laboratories, Boulder, CO USA, 24 pp., 1993.

Oncley, S. P., Foken, T., Vogt, R., Kohsiek, W., De Bruin, H. A. R., Bernhofer, C., Christen, A., Gorsel, E. V., Grantz, D., Feigenwinter, C., Lehner, I., Liebethal, C., Liu, H. P., Mauder, M., Pitacco, A., Ribeiro, L., and Weidinger, T.: The energy balance experiment EBEX-2000, Part I: overview and energy balance, Bound.Lay. Meteorol., 123, 1-28, 2007.

Paulson, C. A.: The mathematical representation of wind speed and temperature profiles in the unstable atmospheric surface layer, J. Appl. Meteorol., 9, 857-861, 1970.

Qin, Z., Zhang, M., Karnieli, A., and Berliner, P.: Mono-window algorithm for retrieving land surface temperature from Landsat TM6 data, Acta Geogr. Sin., 4, 456-466, 2001.

Schmid, H. P.: Footprint modeling for vegetation atmosphere exchange studies: a review and perspective, Agr. Forest Meteorol., 113, 159-183, 2002.

Schüttemeyer, D., Moene, A. F., Holtslag, A. A. M., De Bruin, H. A. R., and De Giesen, N. A.: Surface fluxes and characteristics of drying semi-arid terrain in west Africa, Bound.-Lay. Meteorol., 118, 583-612, 2006.

Steinfeld, G., Letzel, M. O., Raasch, S., Kanda, M., and Inagaki,A.: Spatial representativeness of single tower measurements and the imbalance problem with eddy-covariance fluxes: results of a large-eddy simulation study, Bound.-Lay. Meteorol., 123, 77-98, 2007.

Su, Z., Timmermans, W. J., van der Tol, C., Dost, R., Bianchi, R., Gómez, J. A., House, A., Hajnsek, I., Menenti, M., Magliulo, V., Esposito, M., Haarbrink, R., Bosveld, F., Rothe, R., Baltink, H. K., Vekerdy, Z., Sobrino, J. A., Timmermans, J., van Laake, P., Salama, S., van der Kwast, H., Claassen, E., Stolk, A., Jia, L., Moors, E., Hartogensis, O., and Gillespie, A.: EAGLE 2006 Multi-purpose, multi-angle and multi-sensor in-situ and airborne campaigns over grassland and forest, Hydrol. Earth Syst. Sci., 13, 833-845, doi:10.5194/hess-13-833-2009, 2009.
Suyker, A. E. and Verma, S. B.: Interannual water vapor and energy exchange in an irrigated maize-based agroecosystem, Agr. Forest Meteorol., 148, 417-427, 2008.

Thiermann, V. and Grassl, H.: The measurement of turbulent surface layer fluxes by use of bichromatic scintillation, Bound.-Lay. Meteorol., 58, 367-389, 1992.

Twine, T. E., Kustas, W. P., Norman, J. M., Cook, D. R., Houser, P. R., Meyers, T. P., Prueger, J. H., Starks, P. J., and Wesely, M. L.: Correcting eddy-covariance flux underestimates over grassland, Agr. Forest Meteorol., 103, 279-300, 2000.

Von Randow, C., Kruijt, B., Holtslag, A. A. M., and De Oliveira, A. B. L.: Exploring eddy-covariance and large-aperture scintillometer measurements in an Amazonian rain forest, Agr. Forest Meteorol., 148, 680-690, 2008.

Wang, J. M.: Land Surface Process Experiments and Interaction Study in China - from HEIFE to IMGRASS and GAME Tibet/TIPEX, Plateau Meteorolo, 18, 280-294, 1999.

Wang, T., Ochs, G., and Clifford, S.: Saturation-Resistant optical scintillometer to measure Cn2, J. Opt. Soc. Am., 68, 334-338, 1978.

Wang, W. H,. Liang, S. L., and Meyers, T.: Validating MODIS land surface temperature products using long-term nighttime ground measurements, Remote Sens. Environ., 112, 623-635, 2008.

Webb, E. K.: Profile relationships: The log-linear range and extension to strong stability, Q. J. Roy. Meteorol. Soc., 96, 67-90, 1970.

Wesely, M. L.: The combined effect of temperature and humidity fluctuations on refractive index, J. Appl. Meteorol., 15, 43-49, 1976.

Wever, L. A., Flanagan, L. B., and Carlson, P. J.: Seasonal and interannual variation in evapotranspiration, energy balance and surface conductance in a northern temperate grassland, Agr. Forest Meteorol., 112, 31-49, 2002.

Wilson, K. B. and Baldocchi, D. D.: Seasonal and interannual variability of energy fluxes over a broadleaved temperate deciduous forest in North America, Agr. Forest Meteorol., 100, 1-18, 2000.

Wilson, K. B., Goldstein, A., Falg, E., Aubinet, M., Baldocchi, D., Berbigier, P., Bernhofer, C., Ceulemans, R., Dolman, H., Field, C., Grelle, A., Ibrom, A., Law, B. E., Kowalski, A., Meyers, T., Moncrieff, J., Monson, R., Oechel, W., Tenhunen, J., Valentini, R., and Verma, S.: Energy balance closure at FLUXNET sites, Agr. Forest Meteorol., 113, 223-243, 2002.

Yang, K. and Wang, J. M.: A temperature prediction-correction method for estimating surface soil heat flux from soil temperature and moisture data, Sci. China Ser. D, 51, 721-729, 2008.

Yang, K., Koike, T., and Yang, D.: Surface flux parameterization in the Tibetan Plateau, Bound.-Lay. Meteorol., 116, 245-262, 2003. 